\title{
IN WHICH CLAUSE DO SUBORDINATE CONJUNCTIONS PROSODICALLY BELONG?
}

\author{
ZUZANA KOMRSKOVÁ - PETRA POUKAROVÁ \\ Institute of the Czech National Corpus, Faculty of Arts, Charles University, Prague, \\ Czech Republic
}

\begin{abstract}
KOMRSKOVÁ, Zuzana - POUKAROVÁ, Petra: In which clause do subordinate conjunctions prosodically belong? Journal of Linguistics, 2019, Vol. 70, No 2, pp. 216 224.
\end{abstract}

\begin{abstract}
This paper deals with the position of three Czech subordinating conjunctions že 'that', $k d y z \check{z}$ 'when', and $a \check{z}$ 'when' within the prosodic word, using the phonetic annotation in the ORTOFON corpus. The position of subordinating conjunctions is traditionally described as initial within the subordinate clause, but the situation in spontaneous speech is not so clear. This paper shows the functional differences between the various positions within the prosodic word and presents the words which are most frequently combined with the selected conjunctions.
\end{abstract}

Keywords: conjunction, spontaneous spoken language, spoken corpus, prosody, prosodic word

\section{THEORETICAL BACKGROUND}

Grammar and stylistics usually describe spoken language in opposition to written language in a number of characteristics from all language levels. However, they usually omit the features which belong to sound qualities or which are in close relation to the acoustic channel. Therefore, it is highly valued to use in research such spoken data that are tone-aligned. Thanks to the spoken corpora containing authentic recordings with their transcripts, it is possible to combine research methods for both written and audio data and this data source offers wider possibilities and perspectives for the study of language.

The language-sound relation has been studied for a long time (see e.g. the correspondence between language and phonology units). Perhaps most attention has been paid to the connection between syntax and intonation (e.g. [1], [2], in Czech [3], [4] $)^{1}$, especially to their similar function in communication, which is the ability to delimit the written and spoken texts. The difference between syntax and prosody lies in the perspective of unit description: syntax tends to employ synthesis (the

${ }^{1}$ The description of the role of syntax in spontaneous spoken texts is heavily discussed nowadays (cf. e.g. [5], in Czech [6], [7], but the suprasegmental level is in the spotlight. 
composition of words in mutual syntactic relations to the higher structure within the hierarchy of language levels), while prosody uses analysis (the segmentation of speech continuum). The complementarity of both perspectives plays a functional role in communication, e.g. the distinguishing of the yes/no questions and the declarative sentences, or the functional sentence perspective (the topic structuring and the core of the sentence/utterance).

The important question concerning the delimitation of the written texts and the sound continuum is what the relationship between prosody and punctuation is. The studies dealing with this topic have mainly focused on the read texts (cf. [8], [9], for Czech e.g. [10]). It should be emphasized that punctuation marks, especially commas, could be perceived as a signal of pause. The awareness of this might affect structuring of speech, although speakers naturally group words into semantically coherent phrases indicated by timing and pitch cues; these prosodic phrase boundaries often coincide with major syntactic constituent boundaries but have a much flatter structure than syntax. Prosodic phrase boundaries tend to coincide with commas and semi-colons, but they also occur in other syntactically important places and thus they provide smaller (and potentially more useful) units for processing [11, p. 61], similarly [2, pp. 21, 39].

It was mentioned above that prosody is involved in the segmentation of the speech continuum. For this paper, the prosodic word is considered an elementary unit. It is defined as a group of words (or a single word) associated with one accent. This prosodic unit corresponds to the word in terms of written language. A higher prosodic unit is called tone unit, but the relation to the non-sound language unit is rather unclear. In general, it should be added, that one tone unit corresponds to the syntactically and semantically coherent structure.

Our paper presents an application of the spoken corpus in research on the border of two linguistic disciplines: phonetics and grammar. It focuses on the position of three Czech subordinating conjunctions že 'that', $k d y \check{z}$ 'when', and $a \check{z}$ 'when' within prosodic words. The ORTOFON corpus of spontaneous spoken Czech is used (for the description of the corpus see below).

Previous research about this topic gives contradictory results, based, however, on different data. From the syntactic point of view based on written language, the subordinating conjunctions usually occur in initial position within the subordinate clause (e.g. [12]) and they constitute a structural part of the sentence [13]. According to the orthographic rule, it is necessary to write a comma in front of the subordinating conjunctions in Czech. In accordance with the conclusions of the above-mentioned studies, it could be said that subordinating conjunctions are located at the beginning of the prosodic word.

By contrast, [2, p. 21] claims that the prosodic boundary occurs more often rather after than before a conjunction within spontaneous, unprepared speech. It could correspond to the theory of online syntax, introducing the term projectivity [5] 
and offering the pragmatic point of view: the prosodic boundary occurring after a conjunction enables the speaker to signal her/his intent to continue the speech with some kind of new or known but rephrased information within the following subordinate clause. At the same time, the speaker indicates that s/he needs more time in order to think her/his next statement through.

This paper tries to find out which of above-mentioned points regarding prosodic words are relevant to spoken spontaneous Czech. It combines several perspectives mentioned above trying to cover the holistic and the most complete view on the prosodic words.

\section{DATA AND METHODOLOGY}

The selection of the data source is a key factor for further analysis and the expected results. Since we are interested in the occurrence of prosodic words within the most natural and least prepared spoken language, we chose the ORTOFON corpus [14], which covers spoken everyday communication among family members and friends (for more details see [15]). Moreover, it contains balanced data, and, secondly, it has a multi-tier transcription including not only the orthographic, but also the phonetic layer, containing both segmental and suprasegmental annotation and with the annotation of prosodic words within this phonetic transcription.

We searched for the conjunctions $\check{z} e$ 'that', $k d y \check{z}$ 'when', and $a \check{z}$ 'when' within the recordings with only two speakers. The first two conjunctions belong to the ten most frequent conjunctions in the ORTOFON corpus, whereas the last one is the 12th most frequent conjunction. ${ }^{2}$ These conjunctions were selected according to their indisputable subordinating function.

We separately analyzed the conjunctions at the beginning, at the end, and in the middle of the prosodic word. The middle position means that the conjunction is surrounded on both sides by a different word. Each prosodic word consists of only words, all symbols stand out; therefore the pauses could be found only at the boundaries of the prosodic words. The conjunctions occurred most frequently as the first word within the prosodic word (see Table 1).

\begin{tabular}{|l|r|}
\hline $\begin{array}{l}\text { Position of conjunctions within the } \\
\text { prosodic word }\end{array}$ & Frequency \\
\hline beginning & 18,346 \\
\hline middle & 1,429 \\
\hline end & 6,165 \\
\hline
\end{tabular}

Tab. 1. Frequency of the positions of conjunction within the prosodic word

${ }^{2}$ The frequency of $\check{z} e$ is $21,163, k d y \check{z} 5,173$, and $a \check{z} 1,512$. 
The analysis was primarily focused on the prosodic characteristics of conjunctions. However, we did not analyze solitary words but words in their natural context, therefore it is appropriate and necessary to take into account at least the adjacent words within the prosodic word or within the adjacent prosodic word. As a result, the prosodic analysis, which was conducted manually, was extended to grammatical and semantic characteristics of all items within the prosodic word. These can be transferred into the following questions:

- Which position within the prosodic word does the conjunction occupy?

- Is the conjunction audibly stressed?

- Which parts of speech are included within the prosodic word?

- Is the whole prosodic word used as a collocation ${ }^{3}$ ?

- Do the conjunctions connect the main and the subordinate clauses?

\section{RESULTS}

This section summarizes the results of the whole analysis. It focuses on the position of the conjunction within the prosodic word and is divided into three subsections corresponding to the three possible positions. Some remarks concerning the collocations are added.

As was stated above, the researchers look at the position of the subordinated conjunction within the prosodic word from different points of view (syntactic or phonetic). We tried to describe which viewpoint is dominant and if the position could influence the function of the selected conjunctions.

\subsection{Initial position within the prosodic word}

As was stated above, the ORTOFON corpus is unambiguously dominated by cases where the subordinate conjunctions are at the beginning of the prosodic word (see Table 1). This means that the syntactic point of view - the conjunction as a structural part of the subordinate sentence - is already in agreement with the prosodic division of the sound continuum. Given that one of the most frequent leftsided collocations is a pause, the conjunction is not only the beginning of the prosodic word, but also the beginning of the higher unit, the tone unit.

The results of an analysis, based on random samples of 100 occurrences of conjunctions at the beginning of the prosodic word, could be gathered into three groups.

In the first group, the subordinate conjunction indicates the beginning of the subordinate sentence most frequently (54\%). In this function the conjunction že 'that' occurs predominantly; this is confirmed (and de facto caused) by the most

${ }^{3}$ Since this paper is not focused mainly on collocations, we use this term for such multi-word expressions that have a meaning as a whole unit. 
frequent left-sided collocations, which are formed by verbs requiring a syntax argument in form of the content clauses (verba dicendi, myslet 'think', vědèt 'know', vidèt 'see', etc.). It is not unusual that že occurs even when the main sentence does not contain a verb that would justify its use (tak jsem to hnedka volala mamce shodou okolností u toho telefonu byl i táta že to dala jako na hlasitej hovor 'so I just called my mom and by coincidence my dad was near the phone that she put on speakerphone'), or even in the case of the ellipse of the main clause (it is typical for the reproduction of speech).

The second group could be marked as pragmatic. We classified here the examples, where the conjunction was used as a discourse marker (the collocation že jo 'right', $23 \%$ ), and where the conjunction constitutes the first and the only part of the prosodic word as well (10\%). In this case, the conjunction is used, when the speaker needs more time for thinking about the next statement (oni pro to nemaji ještě senzory jo že .. že . já to úplné citim 'they don't have sensors yet yeah that .. that . I feel it completely'); according to the theory of projectivity (see [1]), the speaker points out to his/her communication partner that he/she is going to continue speaking. Moreover, the repetition of $\check{z} e$ is related to the nature of spontaneous speech that occurs without previous preparation. The use of $\check{z} e$ can be regarded as the evidence not only of its semantic "emptiness" (we can use it when we need time for formulating our statement, and at the same time, we do not imply any relations by using it); but there is a kind of universality of this expression (we can use it anytime): holčičky to tam poslouchaji ne . že tam taky téch cédéček moc nemaji 'the girls listen to it there . that they don't have the CDs there much' (the conjunction že does not belong to the verb contained in the main clause - poslouchat 'listen to' - because its syntactic argument is expressed by the pronoun it, on the contrary, it is possible to replace že with an expression with more appropriate meaning, here maybe with $i k d y \check{z}$ 'although'.

To the third group of the occurrences belong the cases, in which the subordinate sentence is followed by the main clause (13\%). In these cases the conjunctions $k d y z$ 'when' and $a \check{z}$ 'when' are definitely in dominance (77\%). We suppose it could be caused by the syntactic-semantic characteristics of these words. $A \check{z}$ and $k d y \check{z}$ have not only a syntactic function, but a semantic too, and thanks to that their consequence is clear. Compared to that, $\check{z} e$ stays on the borderline between the "introductory segment" and relevant information within the subordinate clause (analogy to functional sentence perspective is evident).

\subsection{Middle position}

The conjunctions occurring in the middle position are the least frequent (see Table 1). The subordinate conjunction, analyzed in this paper, is mainly placed at the second position within the prosodic word. Looking closer at the first position, we found another conjunction in $47 \%$ of all occurrences, then pronouns $(17 \%)$ and adverbs (14\%). Each of these parts of speech is mostly represented by one lemma, 
which is quite opposite to the (mainly third) position after the selected conjunctions. The third position within the prosodic word is most frequently occupied by pronouns and adverbs as the first position, however, there are more verbs and higher number of various lexemes in contrast to the first position. It seems that the third position within the prosodic word is not as fixed by any part of speech as the first position is.

The most frequent conjunction at the first position (covering $68 \%$ of all conjunctions at this position) is $a$ 'and', which is the most frequent conjunction in both spoken and written Czech, followed by conjunctions jako 'like' and $i$ 'also'. Both jako and $i$ are most frequently connected with one conjunction (i.e. jako že 'as though', $i k d y \check{z}$ 'though'), creating together a collocation. The second most predominant lexemes at the first position tak 'so' and to 'it' are used mainly in a collocation as well (see below).

\subsubsection{The ten most frequent prosodic words}

The analysis of prosodic words intersects with the analysis of collocations. The differentiation of a collocation from a non-collocation is conducted according to the meaning of the whole prosodic word; when there were more than $50 \%$ of the prosodic word occurrences used as a unit with one meaning (function), we called it collocation (see the part of the following paragraph in bold).

The ten most frequent prosodic words containing one of the selected conjunctions are the following: to vís že jo 'you bet it is', a že to 'and that it', a že se 'and that', vís že jo 'you bet it is', $a$ že tam 'and that there', a když to 'and when it', ne že by 'not that', a že by 'and that', jako že to 'as though it', tak že se 'so'. Only two prosodic words from the top ten were marked as a collocation, it is the same collocation actually. ${ }^{4}$ This collocation is used as an expression of agreement. The list contains two more collocations (jako že 'as though', tak že 'so'), which do not cover the whole prosodic word, however. They both can be used as a collocation and noncollocation during speech and only the audible analysis could help to distinguish between them. We decided to analyze the collocation tak že 'so that'; namely we were interested in finding out whether in this particular collocation the conjunction $\check{z} e$ is stressed or not (clitic). In 25 cases from 50 occurrences, ${ }^{5}$ the first word - takwas stressed; we supposed that it could be caused by the similarity with the word takže 'so' with the similar meaning and could be written rather as a single word, i.e. non-collocation. In $22 \operatorname{cases}^{6} t a k$ was not stressed, it fulfilled the function of a particle (usually structuring text).

${ }^{4}$ The shorter version appeared because the entire collocation was preceded by the word no. The word sequence no to viš že jo 'but you bet it is' is divided into two prosodic words: no to 'but' and vís $\check{z} e$ jo 'you bet it is'. The boundary between the words višs and že usually coincides during their pronunciation.

${ }^{5}$ This limit was chosen arbitrary.

${ }^{6}$ There were mistakes in transcription and so we have analyzed only 47 occurrences. 
The remaining prosodic words are mainly introduced by the conjunction $a$ 'and'. For comparison: we have analyzed the sample of 50 occurrences of the most frequent non-collocation $a \check{z} e$ 'and that'. We found out that in 49 instances the first member of this phrase $(a)$ is unstressed. It is in accordance with the Czech grammars, which describe this conjunction as a clitic. Finally, the prosodic word ne že by 'not that $\mathrm{sb}^{\prime}$ is used as an opener for the contrast statement.

\subsection{Final position}

The final position of the subordinate conjunctions is much less frequent (see Table 1), but the usage of this conjunction is wider. It can be claimed that different conjunctions appear in different contexts and sometimes the label "conjunction" is relative. The very apparent case is $a \check{z}$ 'when'. Located at the end of the prosodic word, it does not connect any sentences at all, but fulfills the function related to adverbs, or, if appropriate, particles expressing the meaning "extent" (it appears in $6 \%$ of all occurrences). The conjunction $k d y z \check{z}$ 'when' in the collocations co $k d y z$ ('what if'; e.g. co když bude pršet? 'what if it rains?') or $i k d y \check{z}$ 'although' evidence the similar behavior; it does not (syntactically) connect the verb of the main clause, but it primarily expresses the opposite meaning (often as a reaction to communication partner's line). But there were only 6 occurrences in our sample. The phrases going hand in hand with syntactic "relativization" are also evident in the conception of the term main and subordinate clause: consider the collocations stim že 'with that', právě že 'just that', jako že 'like that' (they appear in 9\% of all occurrences). The conjunction $\check{z} e$ (and not the others) as a part of these phrases does not separate sentences into complex sentences but - rather - it structures the text, summarizes information or expresses the reaction to the communication partner:

S1: to jsou klávesy jako nějaké speci*

'these are like keys . some spe*'

S2: takové klávesy a a právě že hodně to frči

'such keys and and just that a lot of it'

In $9 \%$ the conjunctions have the function of a discourse marker (všichni odešli že a já si tak sedim 'everybody had left right and I was sitting and').

But the standard "conjunctional" use of the analyzed words appears most frequently, and so at $40 \%$ in the case of the main clause - the subordinate clause order and $15 \%$ in the reverse order (in the first case že clearly dominates, in the second one $k d y z \check{~ o c c u r s ~ o n l y) . ~}$

The remaining occurrences (13\%) are examples of the speaker not having a clear idea how to continue and/or to formulate his/her statement. In the nearest context pauses, unfinished words and hesitation are found (abych se teda zeptala jak to vypadá že . proč mě 'so I asked how it looks that . why me'). 


\section{SUMMARY}

The paper focused on the position of three Czech subordinate conjunctions in prosodic words in spontaneous spoken language. The analysis showed that, in accordance with syntax descriptions, subordinate conjunctions are most often located at the beginning of a prosodic word. The both initial and final position of the prosodic words demonstrate some common features for all three conjunctions as well as differences.

The most frequent use of these conjunctions as an attaching mean on the complex sentence level is common in both the positions. We figured out that while the conjunction $\check{z} e$ 'that' appears most often in the sequence of main clause subordinate clause, the conjunctions $a \check{z}$ 'when' and $k d y z$ ' 'when' unambiguously prevail in the opposite order of the sequence. This observation should be confronted with the lexical meaning of each conjunction. The conjunction že is used in the main clauses, containing mainly the verbs myslet 'think' and vědět 'know', which could be seen as the introductory segment to the subordinate clause, including the largest piece of new information. On the contrary, the proportion of the amount of the new information included in both main and subordinate clauses with the conjunctions $k d y z \check{z}$ and $a \check{z}$ is rather the same. The semantic difference between these two groups of conjunctions is also described in the dictionary of Czech [16]: $\check{z} e$ has not any specific lexical meaning, whereas $k d y \check{z}$ and $a \check{z}$ do. Therefore, $\check{z}$ e is closer to be called the discourse marker; not only the single-word conjunction, but also the collocation že jo 'right' (cf. [17]) and its expanded version to víš že jo 'you bet it is'.

Considering the differences between the initial and final positions in the prosodic word, they are most pronounced in the case of $a \check{z}$. The initial position is occupied by the conjunction $a \check{z}$, however the part-of-speech-categorization changes at the final position to adverb or particle.

The middle position of the conjunction is interesting in terms of particular cooccurring words in the prosodic word. While the position following the conjunction is occupied by arbitrary parts of speech, the preceding position seems to be restricted, mainly to conjunctions, pronouns and adverbs. In this position, the collocations became also most evident. A further analysis shall focus on collocations separately.

\section{ACKNOWLEDGMENTS}

This study was written within the program Progres Q08 Czech National Corpus implemented at the Faculty of Arts, Charles University. 
[1] Selkirk, E. (1984). Phonology and syntax. Cambridge, MIT.

[2] Wichmann, A. (2000). Intonation in text and discourse. Beginnings, middles and ends. London, Pearson Education Limited.

[3] Daneš, F. (1957). Intonace a věta ve spisovné češtině. Praha, ČSAV.

[4] Palková, Z. (2006). Textové dispozice pro členění na intonační fráze v češtině. In Palková, Z., and Janoušková, J., editors, Kapitoly z fonetiky a fonologie slovanských jazyků, pages 227-239.

[5] Auer, P. (2008). On-line syntax: Thoughts on the temporality of spoken language. Language Sciences 31, pages $1-13$.

[6] Müllerová, O. (1994). Mluvený text a jeho syntaktická výstavba. Praha, Academia.

[7] Hoffmannová, J. et al. (2019): Syntax mluvené češtiny. Praha, Academia.

[8] Chafe, W. C. (1982). Integration and involvement in speaking, writing, and oral literature. In Tannen, D. editor, Spoken and written language: Exploring orality and literacy, pages 35-53.

[9] Chafe, W. C. (1988). Punctuation and the prosody of written language. Accessible at: https://journals. sagepub.com.

[10] Janoušková, J. (2008). Shoda percepčního hodnocení hloubky prozodických předělů v závislosti na struktuře čteného textu. In Volín, J. - Janoušková, J., editors, AUC Philologica 1, Phonetica Pragensia XI, pages 87-104. Praha, Karolinum.

[11] Ostendorf, M. et. al. (2008). Speech segmentation and spoken document processing. Signal Processing Magazine 25(3), pages 59-69.

[12] Hrbáček, J. (1967). K poměru mezi spojovacími prostředky členskými a větnými (Podřadicí spojky v jednoduché větě), Naše řeč 50(3), pages 138-144.

[13] Karlík, P. (2017): SPOJKA. In Petr Karlík, Marek Nekula, Jana Pleskalová (eds.), CzechEncy - Nový encyklopedický slovník češtiny. Accessible at: czechency.org/slovnik/SPOJKA.

[14] Kopřivová, M., Komrsková, Z., Lukeš, D., Poukarová, P., and Škarpová, M. (2017): ORTOFON: Korpus neformální mluvené češtiny s víceúrovňovým přepisem. Praha, Ústav Českého národního korpusu FF UK. Accessible at: http: / / www . korpus . cz .

[15] Komrsková, Z., Kopřivová, M., Lukeš, D., Poukarová, P., and Goláňová, H. (2017): New Spoken Corpora of Czech: ORTOFON and DIALEKT. Jazykovedný časopis 68(2), pages 219-228.

[16] Filipec, J. et al. (2006). Slovník spisovné češtiny pro školu a veřejnost. Praha, Academia.

[17] Komrsková, Z. (2017). What does že jo (and že ne) means in spoken dialogue. Jazykovedný časopis 68(2), pages 229-237. 